\title{
The Graphic Novel: Aesthetic Whitewash or Today's Avant-Garde?
}

Santiago García. 2015. On the Graphic Novel. Trans. Bruce Campbell. Jackson, MS: University Press of Mississippi. 230 pp. ISBN 978-1-62846-481-8

DOI: $10.21066 /$ carcl.libri.2017-06(02).0007

Originally written in Spanish by comics author Santiago García, On the Graphic Novel is a scholarly and compendious study of the graphic novel; the presentation of this volume for an English-speaking readership fully justifies the translator Bruce Campbell's endeavours. García's study came out in 2010, at a time when the graphic novel had become entrenched in the popular imaginary as an art form and was often perceived as antithetical to the lowbrow medium of comics. Suspending value judgements, García merely classifies graphic novels as "another, different formulation for comics" (ix). This may lead comics studies scholars to expect an updating of the critical genealogy established in Will Eisner's Comics and Sequential Art (1985) and Scott McCloud's Understanding Comics: The Invisible Art (1993). García himself appears to offer a precedent for such an expectation. He notes that at the time of his writing, the cultural legitimacy granted to the graphic novel had also somehow influenced the steadily growing presence of comics in high culture, including the literary and artistic worlds - both in traditional centres of comics production, such as the United States and France, as well as in newer sites, including countries such as Spain.

Currently, the elevation of comics to a status of cultural legitimacy has implied that the medium has been frequently viewed as a pedagogical tool: reluctant readers are encouraged to appreciate difficult texts such as Shakespeare's plays through comics adaptations, for example. But for García, attempts to rescue comics from cultural damnation along these lines do injustice to the peculiar excellences of this multimodal medium. For García, comics are more than a mere "hybrid of word and image" (182) whose forte lies in the rich experience offered to the reader. Concurrently, he notes that the term graphic novel is seen by many comics artists as nothing more than a linguistic attempt to dignify the medium. García, however, is not one to opine, in the spirit of Shakespeare's Juliet, that the term graphic novel is nothing but a mere name. Nevertheless, his intention is not to offer an authoritative "definition" (ix), earmarking certain formal features that might pitch the graphic novel against other varieties of comics. For him, such theorisation would be premature, given that the medium is still in a nascent state and as such "has no a priori" (x) stylistic features. Hence, instead of dwelling on the ontological issues of what comics or graphic novels are per se, García proposes to assess empirically what socio-cultural "functions" (x) comics may have performed over time, and where the graphic novel may be situated in this respect.

Chalking out comics "inside a functionalist history" (x) therefore, García apprehends the comic primarily as an art form. However, he also pays attention to the economic history of the medium, taking in, for instance, the respective publishers of comics, their distribution networks, the popularisation of cheap comic books through newsstands, the eventual decline of sales through newsstands and the replacement of sales through other venues such as specialist bookshops, which worked in tandem with the rising culture of comics collectors who frequented comics festivals. Undertaking to "re-write the history of 
comics from the point of view of the graphic novel" (24), García proposes to analyse if a certain variety of comics produced today differs significantly from the varieties of comics produced in the past, and if this endpoint deserves to be named the graphic novel. Thus, the author pleasantly subverts readers' expectations of a possible "definition" (x), as set up in the study's title.

García's historical account turns out to be encyclopaedic in scope, spanning the United States, Europe, and Japan - the three major centres of comics production which have undeniably impacted this cultural field at an international level. In his chronologically calibrated account, García focuses each chapter on a major era in the development of comics, while an abundance of images sampling each era lends visual credence to his readings. Borrowing from but also interrogating former histories of comics written by David Kunzle, David Hajdu, Thierry Smolderen, and Paul Gravett, García recapitulates the $18^{\text {th }}$ and $19^{\text {th }}$ century pictorial traditions of European caricature. Pointing to the Saturnalian impulse in satirical prints and illustrations by William Hogarth in England, Honoré Daumier's mocking sculptures of parliamentarians, and the absurd histoires en estampes of the Swiss writer and educator Rodolphe Töpffer from the 1820s onwards, García demonstrates that comics, from their very inception, were tainted with associations of frivolity and excess characteristic of popular rather than high culture. Nevertheless, the author ascribes the provenance of comics conclusively as a version of mass media in print to the development of newspaper comic strips in New York in the late $19^{\text {th }}$ century. The strips in the Sunday colour supplements of newspapers featured, for example, the recurring character of the Yellow Kid drawn by Richard Felton Outcault, who produced single strips that told the "the joke of the day" (51).

As García reveals, Outcault's use of speech balloons and tendency towards "sequential narration" (47) in the newspaper strip presaged the future development of comics. However, the conditions in which these strips were commonly produced appear to have prefigured the exploitative aspects of the later comics industry: newspaper publishers usually owned the series and their characters, while the artists occupied the status of "mere wage workers in relation to their own creations" (43). In the humorous series which emerged in the 1920s, self-contained narratives appear to have been eventually jettisoned and replaced by longer narratives in which stories continued from one day to the next in successive newspaper issues. Thimble Theatre by E.C. Segar instances such a series, in which Segar brought in the evergreen figure of Popeye the Sailor and his rambunctious adventures at some point. In the 1930s, various series of adventure comics based on larger-than-life figures, including Tarzan and Flash Gordon, took over; Milton Caniff's Terry and the Pirates inaugurated an aesthetic of "realistic effects" on the visual layout of the page, echoing the "narrative model of continuity" in Hollywood cinema (67; emphasis in the original), which would become the defining style of artwork in American comic books. Soon afterwards, publishers of pulp novels appear to have transplanted their assembly-line production systems to the comic book, in which different people specialised in the tasks of drawing, writing, lettering, colouring, and inking, leading to the emergence of mass-produced comics for children, premised commercially upon tried-and-tested formulae. García relates an infamous vignette from this era: DC Comics acquired the rights to the character of Superman from creators Jerry Siegel and Joe Shuster for a measly \$130, shanghaiing the artists' labour and setting in place the dominant model of the American comics industry for decades afterwards. 
At this point, García's history turns from readings underpinned by mass culture theory to a neo-romantic concept of the comics artist as an author, which he sees as foundational to the eventual rise of the graphic novel. In the 1950s, although EC Comics continued to produce cheap, mass-produced comic books, their artists also, unusually for the comics industry, used to sign their own work, and the practice may well have translated into greater personal investment in their productions. According to García, the figure of the author appears to have blossomed, however, with the dawning of the Underground Comix movement in the Swinging Sixties with Robert Crumb as the figurehead. Underground Comix artists produced their works entirely on their own in contrast to the assembly line system of the industry, working at their own pace rather than meeting deadlines set by employers, and did not answer to either editors or the censorship of the Comics Code Authority. Publishing their works themselves or through independent publishers, these artists retained rights to all their works and collected royalties from sales. García points out that some "elements of the underground philosophy" (120) appear to have seeped into the policies of the industry giants as well: in the 1970s, DC finally acknowledged the rights of Jerry Siegel and Joe Shuster as the authors of Superman.

From the late 1970s onwards, the position of the author appears to have been accentuated by the emergence of alternative comics: the magazine Raw, edited by Art Spiegelman \& Françoise Mouly in the 1980s, boldly showcased new and young artists whose work displayed originality. The focus on the author appears to have flowered into a preoccupation with the genres of memoir and autobiography in the graphic novel. Graphic novelist Chris Ware's works such as Jimmy Corrigan, the Smartest Kid on Earth (2000), for instance, unabashedly plumb desperate depths of human emotion. Concurrently, the maturing of the graphic novel as an art form appears to have been accompanied by the authors' assembling of a comics canon through the reclamation of landmark productions in the history of comics. Such productions - or reproductions - include the humorous newspaper family series Gasoline Alley (1918) by Frank King, republished with a new design by Chris Ware in 2005. García thus posits the graphic novel as the culmination of "a process through which the artistic form of the comic has managed to break away from the mass medium of comics", and has "found[ed] a new tradition based on literary and artistic values of its own" (184; emphasis in the original).

The supreme achievement of García's account may lie in his historiographical technique, which adroitly skirts the teleological trap of reading the transition from comics to graphic novels as inevitable. His narrative remains aleatory in construction, accommodating sources for graphic novels in worlds far removed from those of massproduced comic books, which include the picture novels/wordless novels/wordless books of the 1920s-1930s. Printed in woodcut and engraving, these wordless novels shared some formal elements with silent films of the era. Such wordless novels included those of Belgian artist Frans Masereel whose symbolic and allegorical content critiqued the socio-political ills of his time, and works such as his may have a current descendant in Shaun Tan's The Arrival (2006).

A less satisfying aspect of García's study, however, may be his seeming conviction that the graphic novel is a "kind of modern adult comic" (3). Children's literature scholars may well take exception to his position in view of recent publications such as Graphic 
Novels for Children and Young People, edited by Michelle Ann Abate and Gwen Athene Tarbox (2017). Altogether, however, despite having been published a few years ago, On the Graphic Novel remains a highly informative study. Although García professedly addresses himself to comics scholars, specialists and practitioners as well as general readers, his dazzling erudition, enounced in a multilingually sourced bibliography, also makes this study a perfect textbook for university courses in comics and graphic novels.

Malini Roy

\section{Journey through Magic and Imagination}

Michael Levy \& Farah Mendlesohn. 2016. Children's Fantasy Literature: An Introduction. Cambridge: Cambridge University Press. 245 pp. ISBN 978-1-10761029-3

DOI: 10.21066/carcl.libri.2017-06(02).0008

Throughout its history, the development of children's literature has been significantly influenced by various works of the fantasy genre. Nowadays a wide-ranging genre, written not only for children, fantasy literature stems from works which were created for or accepted by a child audience. Although it has always been an important part of children's literature, there are not many theoretical works related to it. Sharing their extensive knowledge of the topic, Michael Levy and Farah Mendlesohn have made a relevant contribution to the study of this field with their monograph Children's Fantasy Literature: An Introduction. Published in 2016 by Cambridge University Press, the book is a result of the continuing collaboration of the authors, their colleagues, and students. As the authors state in their introduction, the aim of the book is to link the criticism of fantasy literature and children's literature in general, because of the strong interrelation of the two genres.

Levy and Mendlesohn have succeeded in finding a manner of expression which can easily be understood by scholars and experts, but also those whose knowledge of fantasy is not yet extensive. Children's Fantasy Literature gives a broad and detailed overview of the development of fantasy literature in the English-speaking world, but its language is still quite accessible to the general reader. In nine chapters, the authors present the most prominent authors and works, as well as the social and political background of the times they belong to. The focus is mainly on the works from British and American literary traditions, but the legacy of the most influential writers of other nations (such as H.C. Andersen and C. Perrault) are also included. The book highlights information about certain influential authors in separate sections.

Although the study of fantasy literature is not highly developed, there are many classifications and categorisations within the genre. In one of her earlier works, Rhetorics of Fantasy (2008), Mendlesohn proposed four subdivisions of the literature of the fantastic: the portal-quest fantasy, the intrusion fantasy, the immersive fantasy, and the liminal fantasy. In the portal-quest fantasy, the everyday world and the fantastic exist separately, connected by magical portals, whereas in immersive fantasy the primary world is the fantastic one. In the intrusion fantasy, the fantastic interferes with the everyday. Liminal fantasy does not include a clear distinction between what is considered fantastical by the protagonist or 